\title{
ANALYSIS OF PASTURE SYSTEMS TO MAXIMIZE THE PROFITABILITY AND SUSTAINABILITY OF GRASS-FED BEEF PRODUCTION
}

\author{
BASU DEB BHANDARI \\ Doctoral Candidate, Department of Agricultural Economics and Agribusiness, Louisiana State University Agricultural \\ Center
}

\section{JEFFREY GILLESPIE*}

Martin D. Woodin Professor, Department of Agricultural Economics and Agribusiness, Louisiana State University Agricultural Center

GUILLERMO SCAGLIA

Associate Professor, Iberia Research Station, Louisiana State University Agricultural Center

JIM WANG

Professor, School of Plant, Environmental and Soil Sciences, Louisiana State University Agricultural Center

MICHAEL SALASSI

Professor, Department of Agricultural Economics and Agribusiness, Louisiana State University Agricultural Center

\begin{abstract}
Pasture systems for grass-fed beef production in the Gulf Coast region were evaluated for profitability and sustainability over the period 2009/2010 to 2011/2012. May-weaned steers were divided into groups and randomly placed into different pasture systems. Data on input usage, output quantities, and carbon emissions were recorded and analyzed. The least complex grazing system yielded higher profit than the most complex, but the most complex produced the lowest greenhouse gas impact. A trade-off was found between profitability and greenhouse gas impact among the systems.
\end{abstract}

Keywords. Bermuda grass, carbon emissions, Dallis grass, grass-fed beef, ryegrass JEL Classifications. Q12, Q15, Q16

\section{Introduction}

A wide range of forage management systems can be used to produce grassfed beef (GFB), with each system resulting in potentially different productivity, profitability, and sustainability outcomes. The U.S. Department of Agriculture

This research is funded in part by Southern SARE (LS09-211), NIFA/AFRI (2011-67023-30098), and HATCH funds (LAB 4178).

*E-mail: JGillespie@agcenter.lsu.edu 
(USDA) defines GFB as beef from cattle whose lifetime diet consists of only grass and other forage, with the exception of milk consumed prior to weaning; no grains are fed (USDA Agriculture Marketing Service, Grass Fed Marketing Claim Standards, 2007). Although GFB preceded grain-fed beef production as a practice of raising cattle, grain supplementation has been standard practice in cattle production since the 1950s (Schupp et al., 1979). Today, the share of GFB production is $<1 \%$ of the total beef produced in the United States (Pelletier, Pirog, and Rasmussen, 2010). Lack of knowledge of appropriate production practices has been cited as one of the reasons for the relative low production of GFB (Gwin, 2009). With increased interest in GFB production in recent years, potential GFB farmers are asking questions about the most profitable production methods.

Over the past 50 years, studies have reported favorable carcass characteristics for grain-fed beef such as juiciness, tenderness, and marbling (Aberle et al., 1981; Fishell et al., 1985; Oltjen, Rumsey, and Putnam, 1971; Young and Kauffman, 1978). Recently, however, with consumer concerns about human health, the environment, and animal welfare, GBF is experiencing increased demand (McCluskey et al., 2005; Mills, 2003; Wright, 2005). Umberger et al. (2002) found that $23 \%$ of U.S. consumers were willing to pay a $\$ 3.00 / \mathrm{kg}$ premium for GFB, and Cox et al. (2006) reported that 33\% preferred GFB and were willing to pay premiums of $\$ 2.38$ to $\$ 5.63 / \mathrm{kg}$. Prevatt, Kerth, and Fields (2006) also reported that a segment of U.S. consumers preferred GFB.

Forage quality can impact beef productivity and quality; thus, it plays a crucial role in animal development and beef production (Gerrish, 2006). Various studies have compared different grazing systems for beef production, many focusing on stocking density (Anderson, 1988; Bertelsen et al., 1993; Lewis et al., 1990) and some also analyzing the economics of those systems (Comerford et al., 2005; Gillespie et al., 2008). Few, however, have focused on GFB production. Surveys of GFB producers have been conducted by Lozier, Rayburn, and Shaw (2005) and Steinberg and Comerford (2009). According to the latter study, the major expenses associated with GFB production were steers, land, feed, equipment, and wintering (hay or silage), the latter four of which are related primarily to forage production. Knowledge of the most profitable forage production systems would greatly benefit GFB producers.

In addition to the selection of an appropriate forage production technology for productivity and profitability, there is a need to investigate the comparative ecological sustainability of forage production systems. Greenhouse gas (GHG) emissions from agricultural land play a role in total global warming potential (GWP). Pasture, as the largest land resource in the United States, plays an important role in carbon cycling and sequestration (Follett and Reed, 2010). Since the Kyoto Protocol of 1997, studies have evaluated the feasibility of carbon sequestration from agricultural and forest land (Antle and McCarl, 2002; Liebig et al., 2010). A wide range of compensation cost for producers for shifting 
their land use to the conservation reserve program $(\$ 12$ to $\$ 500$ per metric ton) was found in eastern Montana depending on the type of land, crop, and cropping intensity (Antle et al., 2001). Zeuli and Skees (2000) analyzed the challenges and opportunities for southern U.S. agriculture to play a role in the carbon market and discussed a wide range of carbon value estimates, which were similar in range to those found by Antle and McCarl (2002). Liebig et al. (2010) evaluated the GHG impacts of different grazing strategies in terms of their contributions to GWP. Limited efforts, however, have been made to evaluate agricultural management strategies in terms of profitability and GHG emissions (Nalley, Popp, and Fortin, 2011; Nalley, Popp, and Niederman, 2013; Williams et al. 2004). For example, McFadden, Nalley, and Popp (2011) and Lyman and Nalley (2013) evaluated rice varieties in Arkansas to maximize profit and minimize GHG emissions. Despite these various efforts, development of a carbon market remains largely in the discussion stage. The present study has implications for what the development of a carbon market might do in encouraging more sustainable agricultural systems.

In this context, we evaluated the profitability and ecological sustainability of three GFB production pasture systems with different levels of management intensity and use of resources. The specific objectives of this study are to determine, for GFB pasture systems, (1) the most profitable system, (2) the system with the lowest GHG emissions, and (3) the potential trade-off between economic profitability and GHG emission reduction. This study is unique not only because it compares the profitability of specific pasture combinations for GFB production, but also because it evaluates carbon emissions related to each of three systems throughout the study period. Trade-offs between profitability and GHG emissions are estimated for the pasture systems. Thus, this study integrates three distinct disciplines of agricultural science: agricultural economics (expenses and returns and trade-offs between GHG impact and economic profitability), animal science (pasture management and rearing of beef cattle), and soil science (analysis of carbon emissions on pasture land).

\section{Analytical Techniques}

This study was based on the following experimental design. Three treatments used in a field experiment at the Iberia Research Station (IRS) in Jeanerette, Louisiana, from 2009/2010 to 2011/2012 represented forage systems with different degrees of management complexity. The three forage systems are as follows:

1. Forage system 1: Bermuda grass as summer pasture; ryegrass as winter pasture.

2. Forage system 2: Bermuda grass as summer pasture; Dallis grass and clover mix as fall and winter pastures; and annual ryegrass, rye, and clover mix (berseem, red, and white clovers) as winter pastures. 
3. Forage system 3: Bermuda grass, sorghum-Sudan hybrid, and forage soybean as summer pastures; Dallis grass and clover mix as fall and winter pastures; and annual ryegrass, rye, and clover mix (berseem, red, and white clovers) as winter pastures.

These systems were chosen as representative of the types of systems currently being used for GFB production in the U.S. Gulf Coast region. The least complex and relatively common system in the Gulf Coast region is represented by system 1 , which consists of perennial summer and winter pasture. System 2 consists of clover mixtures and Dallis grass as an addition to the winter pasture in system 1. This would help to extend the grazing period and reduce the requirement of hay feeding. Sorghum-Sudan hybrid and soybean are added in system 3 as summer pasture in addition to system 2 , which would help to satisfy the nutritive requirements of steers. Thus, system 1 is the least complex system, and system 3 is the most complex system.

The same pastures were used for each treatment each year. The experimental year began in May and ended by the end of April the following year. The three forage systems were managed in different subpaddocks at the IRS, rotated among the subpaddocks based on forage availability. Annually, 54 fall-born steers (78 months old) were assigned to one of the three forage systems immediately after weaning and remained until time of harvest at age 17-19 months. The steers were blocked at weaning by weight into nine groups (6 steers/group). Each group was randomly assigned to one of the three treatments, each of which was replicated three times. During the transition period when forage availability was low (mid-November to December), animals were fed hay produced in the paddocks allocated to the system/replication group. Records were kept on the amount of hay fed to each group. Constructed portable shades were made available for the animals in each group. They were moved along with the animals when rotated. Water and mineral mix were available at all times. The stocking rate was 1 hectare per animal for each entire system. Although this may seem to be a relatively low stocking rate at first glance, unpublished survey results of a mail survey we sent to all identified southern U.S. GFB producers show that it is not uncommon to have a stocking rate in this range considering the lowest forage production period in the year.

Detailed cost and input records were kept for each pasture by year, with sheets on which the records were to be kept developed by the authors. These records detailed the agronomic operations, labor activity, and input usage in each pasture, recorded in a field book. These records were used to develop detailed cost and return estimates for each treatment/replication. Budgets included returns, direct expenses, fixed expenses, and land rent. The expenses of seed, fertilizer, pesticide, minerals, medication, twine, fuel, purchased weaned steers, repair and maintenance of machinery, and interest on operating capital were included in the direct expenses. Depreciation and interest on machinery (trucks, tractors, and 
Table 1. Prices of Inputs and Outputs for the Experimental Years

\begin{tabular}{|c|c|c|c|c|}
\hline \multirow[b]{2}{*}{ Inputs/Outputs } & \multirow[b]{2}{*}{ Units } & \multicolumn{3}{|c|}{ Price in US\$ } \\
\hline & & 2009 & 2010 & 2011 \\
\hline Urea & Kilogram & 0.40 & 0.35 & 0.42 \\
\hline Gramoxone Max & Liter & 10.57 & 11.54 & 11.54 \\
\hline Grazon P+D & Liter & 8.47 & 10.44 & 8.18 \\
\hline Roundup Original Max & Liter & 13.86 & 15.32 & 12.85 \\
\hline Outrider & Liter & 676.28 & N/A & N/A \\
\hline Platoon & Liter & N/A & N/A & 3.70 \\
\hline Malathion & Liter & N/A & 8.98 & 8.94 \\
\hline Sevin $80 \mathrm{WP}$ & Kilogram & 13.51 & 15.01 & 16.20 \\
\hline Bovishield & Dose & 2.50 & 2.50 & 2.50 \\
\hline One Shut & Shut & 2.50 & 2.50 & 2.50 \\
\hline Sweetilix & Bag & 18.00 & 18.00 & 18.00 \\
\hline Ultrabac 8 & Dose & 0.40 & 0.40 & 0.40 \\
\hline Vigortone 3V2 & Bag & 26.20 & 26.20 & 26.20 \\
\hline Vigortone 3V5 & Bag & 17.13 & 17.13 & 17.13 \\
\hline Weanling calf & Kilogram & 2.17 & 2.51 & 2.51 \\
\hline Twine & Ton & 0.75 & 0.75 & 0.75 \\
\hline Berseem clover seed & Kilogram & 4.72 & 4.74 & 7.72 \\
\hline Red clover seed & Kilogram & 5.51 & 6.61 & 2.65 \\
\hline White clover seed & Kilogram & 5.51 & 7.05 & 6.83 \\
\hline Rye seed & Kilogram & 0.49 & 0.97 & 0.99 \\
\hline Ryegrass seed & Kilogram & 1.34 & 1.54 & 1.10 \\
\hline Soybean seed & Kilogram & 1.23 & 1.17 & 1.32 \\
\hline Sorghum-Sudan seed & Pound & 0.47 & 0.80 & 0.80 \\
\hline Hay $^{\mathrm{a}}$ & Bale & 45.00 & 40.00 & 82.50 \\
\hline Steers at harvest ${ }^{\mathrm{a}}$ & Kilogram & 2.56 & 2.93 & 3.11 \\
\hline Diesel fuel & Liter & 0.58 & 0.61 & 0.73 \\
\hline
\end{tabular}

a Although the prices of hay and steer at harvest were tabulated as 2009, 2010, and 2011, those were based on U.S. Department of Agriculture prices in the following years (2010, 2011, and 2012) because the harvesting and selling of hay and steers was in the second calendar year of the experiment.

Note: N/A indicates data not available.

other implements), permanent fencing, and temporary fencing were included in the fixed expenses. The opportunity cost of land rental was included.

Table 1 includes annual prices of inputs and outputs. Most of the input prices are those used by Boucher and Gillespie $(2009,2010,2011)$ for cost and return estimates for cattle and forage production. Weaned calf prices from Louisiana Agricultural Statistics 2011 were used (LSU Agricultural Center, USDA-NASS, 2012). We used calf prices from the second quarter of each year from 2009 to 2011 because animals entered the experiment in May. Hay prices were determined based on those listed in the Weekly Texas Hay Report (USDATexas Department of Agricultural Marketing News, 2010, 2011, and 2012) for fair quality hay, assuming any leftover hay was sold in April after harvest of the animals. The grass-fed steer price was based on USDA Economic Research 
Table 2. Prices of Fixed Inputs, Machinery, and Equipment

\begin{tabular}{|c|c|c|c|}
\hline \multicolumn{4}{|c|}{ Fixed Input Annual Costs in US\$ } \\
\hline & Units & Repair and Maintenance & Fixed Costs \\
\hline Fence electric & Kilometer & 23.61 & 156.19 \\
\hline Fence 5 wire & Kilometer & 130.49 & 302.30 \\
\hline Hay rack & Each & 9.04 & 26.27 \\
\hline Shade structure & Each & 3.48 & 72.65 \\
\hline Shade cloth & Each & 5.30 & 64.25 \\
\hline Water tank and pump & Each & 40.00 & 132.50 \\
\hline \multicolumn{4}{|c|}{ Machinery and Equipment Costs in US\$ } \\
\hline Machinery/Equipment & & Direct Costs/Hour & Fixed Costs/Hour \\
\hline Mower conditioner & & 10.79 & 12.89 \\
\hline Hay rake & & 2.43 & 3.16 \\
\hline Hay tedder & & 2.45 & 3.67 \\
\hline Hay fork & & 0.09 & 0.22 \\
\hline Baler round & & 13.98 & 18.56 \\
\hline Mower drum & & 4.68 & 5.59 \\
\hline Boom sprayer & & 2.35 & 3.12 \\
\hline Tractor $(40-59 \mathrm{hp})$ & & 6.48 & 4.42 \\
\hline Tractor (60-89 hp) & & 10.05 & 7.81 \\
\hline Tractor $(90-115 \mathrm{hp})$ & & 14.31 & 12.52 \\
\hline
\end{tabular}

Service (Johnson 2012) published prices for fed steers in the second quarter of each year and adjusted by adding $\$ 0.44 / \mathrm{kg}$ to the fed steer price, as suggested by a manager of one of the larger GFB production firms. As the records were kept by group for each year, there were 9 sets of records per year, for a total of 27 sets of records and 27 resulting cost and returns estimates for the 3 years.

Table 2 shows fixed inputs with their annual fixed and repair and maintenance costs. These costs were calculated according to their useful life as the costs of capital and depreciation. Similarly, the fixed expenses of machinery and equipment were estimated as depreciation and opportunity cost of capital (interest) by hours of use, assuming a useful life of a fixed number of hours as shown in Boucher and Gillespie (2011).

Differences in fixed expenses, variable expenses, gross returns, and net returns among treatments were determined using a mixed model with fixed treatments, and years as fixed repeated measures effects. The Kenward-Roger degrees of freedom method was used (Kenward and Roger 1997).

Because the cost and returns analysis is based on 27 observations, we used simulation and dominance techniques to strengthen the results of this research. Based on historical data (10 years, 2002-2011) on prices of inputs (fertilizer, fuel, and calf) and outputs (hay and steer), 1,000 randomly simulated values were developed using Simetar, a commercial mathematical simulation software 
package (Richardson, Schumann, and Feldman, 2008). Similarly, hay yield was estimated based on 10 years of historical rainfall data at the IRS, and 1,000 randomly simulated values were developed. Other input prices and quantities and steer yield were taken as constant because we did not observe significant variation in these input and output prices and quantities over the course of the experiment. Based on these simulated values and constant values, 1,000 net returns for each of the systems were developed.

Using the 1,000 simulated net returns, we estimated certainty equivalents (CEs) assuming different risk aversion coefficients for each system according to the relationship outlined by Hardaker et al. (2004). The CE is the net return value held with certainty at which the decision maker is indifferent to a risky distribution of net return values. Estimation of the CE depends on the utility function of the decision maker. Equation (1) gives the relationship between the utility function $U(w)$ and the absolute risk aversion coefficient $r_{a}(w)$,

$$
U(w)=-\exp \left[-r_{a}(w)\right]
$$

where $w$ is the wealth or income associated with the choice. The absolute risk aversion coefficient is defined as the negative ratio of the second and first derivatives of the utility function as shown in equation (2).

$$
r_{a}(w)=-\frac{u^{\prime \prime}(w)}{u^{\prime}(w)}
$$

The relationship between the absolute risk aversion coefficient and the relative risk aversion coefficient, $r_{r}(w)$, is expressed as follows:

$$
r_{a}(w)=\frac{r_{r}(w)}{w} \text {. }
$$

The CE for a random sample of size $n$ from risky alternatives $w$ is estimated as follows, as shown by Hardaker et al. (2004):

$$
\mathrm{CE}\left[w, r_{a}(w)\right]=\ln \left(\left\{\frac{1}{n} \sum_{i}^{n} \exp \left[-r_{a}(w) w_{i}\right]\right\}^{-1 / r_{a}(w)}\right)
$$

As Anderson and Dillon (1992) have proposed, a general classification of relative risk aversion coefficients falls in the range of 0 for risk neutral to 4 for highly risk averse. Absolute risk aversion coefficients were obtained by dividing a range of relative risk aversion coefficients ( 0 to 4 ) by the estimated mean net return of system 3 . This gives the maximum absolute risk aversion coefficient of 0.0024 , which is used in a stochastic efficiency with respect to function (SERF) analysis. SERF is a means to evaluate the risky alternatives in terms of CEs for a specified range of absolute risk aversion coefficients. It is superior to stochastic dominance with respect to function because the latter only makes the pairwise comparison (Hardaker et al., 2004). The result is graphed to 
analyze the dominance by system. We used a similar method to that of Hardaker et al. (2004) to analyze the SERF among the systems.

\subsection{Estimating Carbon Emissions}

Soil carbon emission data and soil samples were collected and analyzed within the three pasture systems. There were seven different forage categories. For each category, gas sampling for carbon dioxide $\left(\mathrm{CO}_{2}\right)$ and atmospheric methane $\left(\mathrm{CH}_{4}\right)$ flux was carried out. Four chambers (replicates) were placed in pastures for each forage category. Samples were taken monthly throughout the experiment. Chamber gas samples at each location were taken at regular intervals of 0,30 , and 60 minutes. These samples were analyzed by gas chromatography equipped with a methanizer and flame ionization detector. The $\mathrm{CO}_{2}$ and $\mathrm{CH}_{4}$ fluxes were computed from the rate of change in chamber concentration, chamber volume, and soil surface area. We were, thus, able to compute the annual average $\mathrm{CO}_{2}$ equivalent carbon emissions by pasture system. Because $\mathrm{CO}_{2}$ equivalent carbon emissions from the atmospheric $\mathrm{CO}_{2}$ flux, $\mathrm{CH}_{4}$ flux, and nitrous oxide $\left(\mathrm{N}_{2} \mathrm{O}\right)$ flux data were collected based on different pasture types, not from the individual subpaddocks, we could not develop 27 separate sets of data for $\mathrm{CO}_{2}$ emissions specific to a system. Therefore, we could not apply statistical analysis on $\mathrm{CO}_{2}$ emissions, so only the arithmetic means for each system were compared for the analysis.

The net GWP in kilograms of $\mathrm{CO}_{2}$ equivalent in each system was determined by summing the emitted $\mathrm{CO}_{2}$ equivalents from seven factors as shown in the following equation used by Liebig et al. (2010), with modification:

$$
\mathrm{GWP}=\mathrm{NP}+\mathrm{EF}+\mathrm{CO}_{2} \text { flux }+\mathrm{N}_{2} \mathrm{O} \text { flux }+\mathrm{CH}_{4} \text { flux }+\mathrm{DU}+\mathrm{PP},
$$

where GWP is measured in kilograms of $\mathrm{CO}_{2}$ equivalent emissions summing from different sources; NP is the $\mathrm{CO}_{2}$ equivalent emission by nitrogen fertilizer production; $\mathrm{EF}$ is the $\mathrm{CO}_{2}$ equivalent emission via thorough enteric fermentation; $\mathrm{CO}_{2}$ flux is the $\mathrm{CO}_{2}$ equivalent emission through atmospheric $\mathrm{CO}_{2}$ surrounding the pasture; $\mathrm{N}_{2} \mathrm{O}$ flux is the $\mathrm{CO}_{2}$ equivalent emission through atmospheric $\mathrm{N}_{2} \mathrm{O}$ flux; $\mathrm{CH}_{4}$ flux is the $\mathrm{CO}_{2}$ equivalent emission through $\mathrm{CH}_{4}$ flux; DU is the $\mathrm{CO}_{2}$ equivalent emission by diesel use, which includes diesel used in fertilizer and pesticide application, tillage, and hay operations; and PP is the $\mathrm{CO}_{2}$ equivalent emission by pesticide production.

Equation (5) was modified from Liebig et al. (2010) by replacing the change in soil organic carbon with $\mathrm{CO}_{2}$ flux, as the change in soil carbon as measured in the study through soil sampling was barely noticeable over the 3-year period of our study. A much longer period of soil sampling would have been required to begin to detect differences in soil carbon, presenting challenges for the collection of such data in most studies of this type. Additionally, in Liebig et al. (2010), NP consists of two parts (i.e., nitrogen production and application). In our study, the application portion is included in DU. Because Liebig et al. (2010) did not apply 
any pesticides or include any field operations, DU and PP were not included in their equations.

Nitrogen fertilizer used in each system was aggregated based on annual use in the respective pasture systems; $\mathrm{CO}_{2}$ equivalent emission from NP was computed as in Liebig et al. (2010). Similarly, $\mathrm{CO}_{2}$ equivalent emission from EF was computed as in Liebig et al. (2010), in which they assumed similar $\mathrm{CO}_{2}$ equivalent emissions from EF per animal among different systems. Atmospheric $\mathrm{CO}_{2}-\mathrm{C}$ flux, $\mathrm{N}_{2} \mathrm{O}-\mathrm{N}$ flux, and $\mathrm{CH}_{4}-\mathrm{C}$ flux were calculated based on laboratory analysis of field samples. The conversion of $\mathrm{CO}_{2}-\mathrm{C}$ flux to $\mathrm{CO}_{2}$ equivalent emission was conducted by multiplying by the conversion factor 3.667, and the conversions of $\mathrm{N}_{2} \mathrm{O}-\mathrm{N}$ flux and $\mathrm{CH}_{4}-\mathrm{C}$ flux were conducted by multiplying by conversion factors of 298 and 25, respectively, as in Liebig et al. (2010). The carbon equivalent emission from DU was estimated by multiplying the conversion factor of $0.94 \mathrm{~kg}$ carbon equivalent per $\mathrm{kg}$ of diesel as in Lal (2004), which was further converted to $\mathrm{CO}_{2}$ equivalent emission by multiplying by the conversion factor, 3.667. Pesticide used in each system was aggregated based on annual use. Then the carbon equivalent emission from PP was calculated by summing the carbon equivalents from different pesticides used as in Lal $(2004)^{1}$ and further converted into $\mathrm{CO}_{2}$ equivalent emission by multiplying by the conversion factor 3.667. As the conversion factors in Lal (2004) are based on kilograms of active ingredients, liquid formulations were converted to quantities by using the specific gravity of the pesticides in solution as a multiplying factor (Table A1 in the Appendix). Because we could not find the specific conversion factors for picloram, sulfosulfuran, and dimethylamine salt of 2,4-D to estimate $\mathrm{CO}_{2}$ equivalent emission, the general conversion factor for herbicides, 4.4, was used as estimated in West and Marland (2002). Because these three active ingredients of herbicides contributed $<1 \%$ of the total pesticides used for this experiment, they would have minimal impact on the $\mathrm{CO}_{2}$ equivalent emission.

Equation (5) is further modified by subtracting the $\mathrm{CO}_{2}$ equivalent carbon sequestration from hay surplus (HS) as follows:

$$
\mathrm{GWP}=\mathrm{NP}+\mathrm{EF}+\mathrm{CO}_{2} \text { flux }+\mathrm{N}_{2} \mathrm{O} \text { flux }+\mathrm{CH}_{4} \text { flux }+\mathrm{DU}+\mathrm{PP}-\mathrm{HS} .
$$

HS is the quantity of hay biomass remaining after consumption by the animals in the respective pasture systems. Carbon sequestered in this HS is calculated by subtracting the $12 \%$ moisture from hay biomass and multiplying by the conversion factor 0.475 . This is then converted into $\mathrm{CO}_{2}$ equivalent by multiplying by the conversion factor 3.667. Because HS fixed atmospheric carbon, it would negatively affect the net GWP. Therefore, it has a negative sign in equation (6). Ultimately, this carbon sequestered in the HS would likely

1 Carbon equivalent conversion factors for different active ingredients as per Lal (2004) are as follows: 1.7 for 2,4-D, 9.1 for glyphosate, 9.2 for paraquat, 4.6 for malathion, and 9.1 for carbaryl. 
be released to the atmosphere because the HS will be used for consumption by animals. Therefore, we calculated the GWP with and without including HS.

The value of carbon that would entice farmers to switch management practices (treatments) was determined. The value of carbon emissions was determined by comparing the total amount of $\mathrm{CO}_{2}$ equivalent GWP and economic profit per animal per year among the systems, as in equation (7),

$$
\pi_{k}=\pi_{l}+C
$$

where $\pi_{k}$ is the profit associated with system $k$ (without placing economic value for $\mathrm{CO}_{2}$ equivalent carbon emissions); $\pi_{l}$ is the profit associated with system $l$ (without placing economic value for $\mathrm{CO}_{2}$ equivalent emissions); and $\mathrm{C}$ is the value of reduced $\mathrm{CO}_{2}$ equivalent carbon emissions that would induce a change from system $k$ to system $l$.

\section{Results and Discussion}

\subsection{Economic Profitability by System}

Return, expense, and profit estimates for the three systems are presented in Table 3. Results are reported on a per steer basis. Because the stocking density is 1 steer per hectare, this can be taken as a per hectare basis as well. Differences in steer income were not found among the treatments in this experiment because the animal weights at the time of harvest did not differ significantly among the systems. Mean weights of finished animals were $462 \mathrm{~kg}, 458 \mathrm{~kg}$, and $459 \mathrm{~kg}$ for systems 1, 2, and 3, respectively (Table 4). Hay income differed significantly among the systems (i.e., greatest in system 1 and least in system 3 ) because hay production was more extensive in Bermuda grass and ryegrass pastures than in other pastures. System 1 had greater proportions of Bermuda grass and ryegrass pasture than system 3. Little hay was made with clovers, sorghum-Sudan hybrid, soybean, and so forth, as there was little excess forage to be harvested in those crops. Average gross returns per steer were $\$ 2,129, \$ 1,984$, and $\$ 1,772$, for systems 1,2 , and 3, respectively, noninclusive of any partial carbon sequestration benefits. Each differed significantly from the others. The gross return was highest in system 1 and lowest in system 3 due primarily to the differences in hay income among these systems.

Fertilizer expense for system 1 was significantly greater than for systems 2 and 3. This was due to higher usage of nitrogen-fixing legumes in systems 2 and 3, which substituted for commercial nitrogen fertilizer. Pesticide expense did not differ significantly among the systems, although it was numerically slightly greater in system 3 due to higher use of Outrider, which was not used in system 1. Livestock expense did not differ among the systems because equal-weight weaned animals were used across the treatments. Twine expense was greater in system 1 than in systems 2 and 3 because it was used on more bales of hay produced. Seed expense differed among the three systems, with the lowest in system 1 
Table 3. Revenue, Expenses, and Profit per Treatment (US\$ per Animal)

\begin{tabular}{lccc}
\hline \hline Item & System 1 & System 2 & System 3 \\
\hline Income & & & \\
Steer income & $1,324.41$ & $1,330.17$ & $1,311.61$ \\
Hay income & $804.20^{\mathrm{bc}}$ & $653.37^{\mathrm{ca}}$ & $460.31^{\mathrm{ab}}$ \\
Total income & $2,128.61^{\mathrm{bc}}$ & $1,983.56^{\mathrm{ca}}$ & $1,771.94^{\mathrm{ab}}$ \\
Expenses & & & \\
Fertilizer & $238.37^{\mathrm{bc}}$ & $173.50^{\mathrm{ac}}$ & $145.52^{\mathrm{ab}}$ \\
Pesticide & 48.54 & 45.65 & 52.82 \\
Livestock & 620.98 & 622.93 & 623.35 \\
Twine & $3.96^{\mathrm{bc}}$ & $2.91^{\mathrm{a}}$ & $2.41^{\mathrm{a}}$ \\
Seed & $68.52^{\mathrm{bc}}$ & $142.37^{\mathrm{ac}}$ & $201.89^{\mathrm{ab}}$ \\
Minerals, medication & $22.17^{\mathrm{bc}}$ & $22.69^{\mathrm{a}}$ & $22.65^{\mathrm{a}}$ \\
Diesel expense & $74.96^{\mathrm{bc}}$ & $56.46^{\mathrm{a}}$ & $48.03^{\mathrm{a}}$ \\
Repair and maintenance & $64.96^{\mathrm{bc}}$ & $51.76^{\mathrm{a}}$ & $48.06^{\mathrm{a}}$ \\
Interest on operating capital & 47.22 & 48.07 & 46.56 \\
Total direct expense (D) & $1,190.28$ & $1,161.93$ & $1,192.02$ \\
Return over total direct expense & $938.26^{\mathrm{c}}$ & $816.57^{\mathrm{c}}$ & $579.87^{\mathrm{ab}}$ \\
Fixed expense (F) & $214.48^{\mathrm{bc}}$ & $170.04^{\mathrm{ac}}$ & $147.24^{\mathrm{ab}}$ \\
Total expenditure (D + F) & $1,404.78$ & $1,337.07$ & $1,339.39$ \\
Return over specified expenses & $723.44^{\mathrm{c}}$ & $646.44^{\mathrm{c}}$ & $432.50^{\mathrm{ab}}$ \\
Residual return & $641.33^{\mathrm{c}}$ & $572.17^{\mathrm{c}}$ & $360.39^{\mathrm{ab}}$ \\
Residual returns per labor hour & 33.65 & 35.35 & 25.04 \\
Residual returns with labor & $452.35^{\mathrm{c}}$ & $411.30^{\mathrm{c}}$ & $217.43^{\mathrm{ab}}$ \\
\hline \hline
\end{tabular}

Notes: Residual Return $=$ Total Income - Direct Expense - Fixed Expense - Land Rent. System 1 represents the simplest pasture system including Bermuda grass and ryegrass. System 2 includes a clover mix in addition to grasses in system 1, and system 3 includes sorghum-Sudan hybrid and soybean in addition to the forage in system 2 .

a Means differ significantly from system 1 within rows at $P<0.05$.

b Means differ significantly from system 2 within rows at $P<0.05$.

${ }^{c}$ Means differ significantly from system 3 within rows at $P<0.05$.

and the highest in system 3. This was due to the greater diversity of pastures in system 3 compared with only Bermuda grass and ryegrass in system 1 , the former of which is a permanent (perennial) pasture. Instead of including variable expenses for seeding Bermuda grass pastures (assuming these had been previously established as permanent pastures), the establishment expense for Bermuda grass was included as a fixed expense as in Boucher and Gillespie (2009, 2010, 2011). Minerals and medication expenses were greater in systems 2 and 3 than in system 1. This was due to the use of Sweetlix to control bloat in systems 2 and 3 with legume pastures, but not in system 1 . Diesel expense was greater in system 1 than systems 2 and 3, primarily because of the greater use of machinery for hay cutting and baling in system 1. Similarly, repair and maintenance expense was also greater in system 1 than systems 2 and 3 because of greater use of machinery for hay cutting and baling. 
Table 4. Steer and Hay Measures

\begin{tabular}{|c|c|c|c|c|}
\hline \multirow[b]{2}{*}{ System } & \multicolumn{2}{|c|}{ Average Weight per Steer in Kilograms } & \multicolumn{2}{|c|}{ Number of Hay Bales } \\
\hline & Initial & Final & Produced & Fed \\
\hline System 1 average & 259 & 462 & 96 & 6 \\
\hline 2009 & 255 & 461 & 54 & 7 \\
\hline 2010 & 247 & 459 & 148 & 4 \\
\hline 2011 & 273 & 466 & 86 & 6 \\
\hline System 2 average & 260 & 458 & 80 & 5 \\
\hline 2009 & 258 & 445 & 81 & 7 \\
\hline 2010 & 246 & 469 & 101 & 3 \\
\hline 2011 & 275 & 459 & 58 & 4 \\
\hline System 3 average & 260 & 459 & 59 & 5 \\
\hline 2009 & 256 & 440 & 64 & 6 \\
\hline 2010 & 247 & 463 & 73 & 5 \\
\hline 2011 & 275 & 474 & 40 & 5 \\
\hline
\end{tabular}

Notes: System 1 represents the simplest pasture system including Bermuda grass and ryegrass. System 2 includes a clover mix in addition to grasses in system 1, and system 3 includes sorghum-Sudan hybrid and soybean in addition to the forage in system 2 .

In total, direct expenses did not differ significantly among the systems, the major reason being relatively high fertilizer and diesel expenses in system 1 and higher seed expenses in system 3 . The return over direct expenses was higher for systems 1 and 2 than for system 3. Fixed expense differed among the systems. Assuming 50 animals on the farm, system 1 consisted of 4.18 kilometers of permanent fencing and 0.89 kilometers of temporary fencing. System 2 included 3.99 kilometers of permanent and 0.47 kilometers of temporary fencing. System 3 included 4.25 kilometers of permanent fencing only. Fixed cost was highest for system 1 due primarily to the greater use of machinery for hay harvesting and baling and the fixed expense associated with establishing Bermuda grass pastures. Altogether, total specified expenses per steer were $\$ 1,405, \$ 1,337$, and $\$ 1,339$ for systems 1,2 , and 3, respectively.

Net returns per steer were $\$ 641, \$ 572$, and $\$ 360$ for systems 1,2 , and 3, respectively, with the net profit of systems 1 and 2 being significantly greater than that of system 3 . The net return estimates are in the range of magnitudes found by Steinberg and Comerford (2009), $-\$ 198 \pm 1,596.90$ per steer. The average labor hours required for systems 1,2 , and 3 were 19.1, 16.2, and 14.4, respectively, and returns per labor hour were $\$ 34, \$ 35$, and $\$ 25$ for systems 1 , 2 , and 3 , respectively. When we considered the labor and management expenses from the residual returns, returns per steer were $\$ 452, \$ 411$, and $\$ 217$ for systems 1, 2, and 3, respectively (Table 3).

Results of the SERF analysis are presented in Figure 1. The results show that systems 1 and 2 clearly dominate system 3 and confirm the findings of the cost and returns analysis. Due to the stochastic nature of hay production in system 1 , 


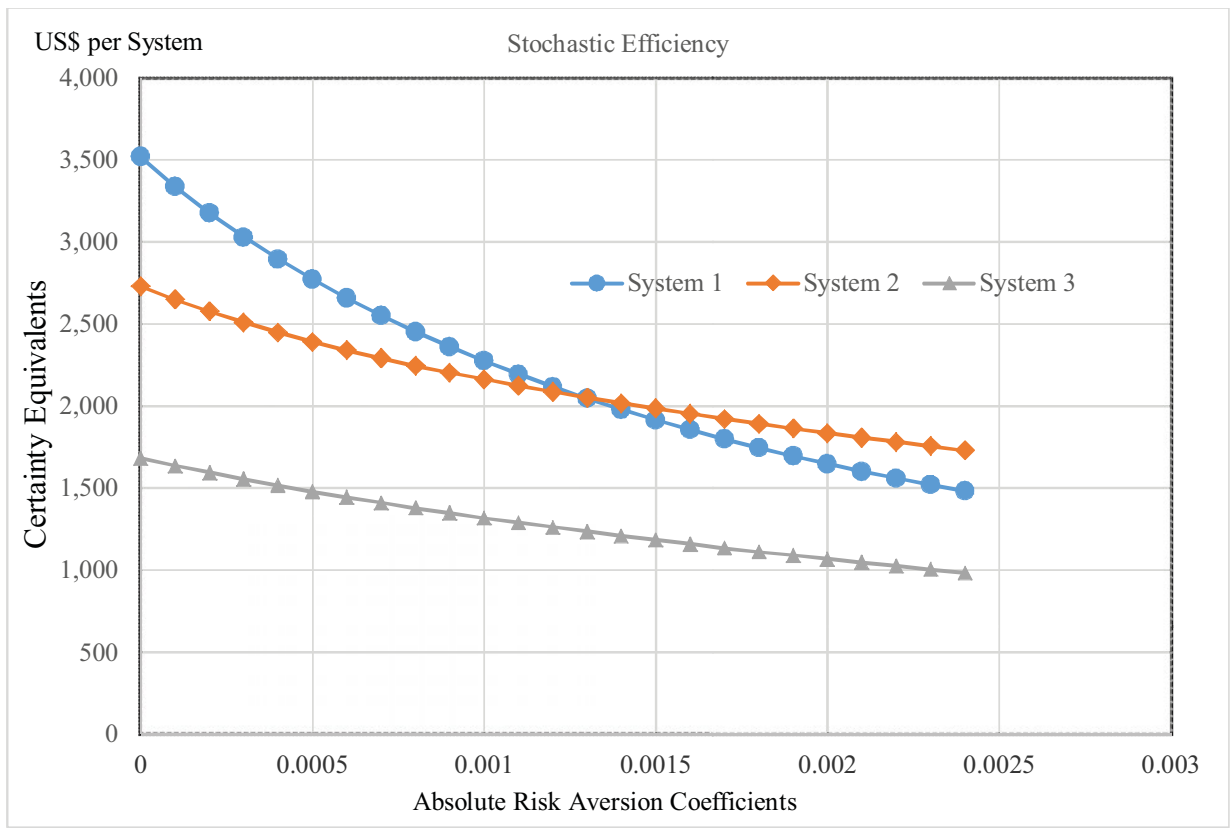

Figure 1. Stochastic Efficiency with Respect to a Function among the Systems

decision makers with risk aversion coefficients of 0.0013 or less would choose system 1 over system 2 , whereas decision makers having risk aversion coefficients greater than 0.0013 would choose system 2 over system 1 . Thus, the results show that more risk averse producers would choose system 2, whereas less risk averse producers would choose system 1 . System 2 had associated net returns that were less variable than in system 1 due to higher variability of hay production in system 1 .

\subsection{Greenhouse Gas Emissions}

Annual $\mathrm{CO}_{2}$ emissions data were collected by pasture type and aggregated for each pasture system. Estimated $\mathrm{CO}_{2}$ equivalent emissions from NP; EF; $\mathrm{CH}_{4}$, $\mathrm{N}_{2} \mathrm{O}$, and $\mathrm{CO}_{2}$ fluxes; DU; and PP per system as well as $\mathrm{CO}_{2}$ equivalent fixation by HS per system are presented in Table 5, as are the net annual GWP with and without HS per system and per animal per year. Because HS from each system was sold and income due to hay sale was included in economic profit measures, GWP per steer per year was also estimated without subtracting HS as in equation (5). Although the amount of GWP per steer per year was slightly higher in each system without HS, the difference was not great.

System 3 produced the lowest annual GWP per steer, 52,281 kg of $\mathrm{CO}_{2}$ equivalent GWP, whereas system 1 produced the highest, 68,556 kg of $\mathrm{CO}_{2}$ equivalent GWP. On average, $3,735 \mathrm{~kg}, 2,721 \mathrm{~kg}$, and 2,475 kg total of nitrogen 
Table 5. Global Warming Potential (GWP) as Kilograms $\mathrm{CO}_{2}$ Equivalent per Year among Systems with and without Hay Surplus per Treatment per Animal

\begin{tabular}{|c|c|c|c|c|c|c|c|c|c|c|c|c|}
\hline \multirow[b]{2}{*}{ System } & \multicolumn{8}{|c|}{ Kilograms $\mathrm{CO}_{2}$ Equivalent per Year from Different Sources } & \multicolumn{2}{|c|}{ GWP with HS } & \multicolumn{2}{|c|}{ GWP without HS } \\
\hline & NP & $\mathrm{EF}$ & $\mathrm{CH}_{4} \mathrm{~F}$ & $\mathrm{~N}_{2} \mathrm{O} \mathrm{F}$ & $\mathrm{CO}_{2} \mathrm{~F}$ & HS & DU & $\mathrm{PP}$ & GWP & GWP/Animal & GWP & GWP/Animal \\
\hline System 1 & 5,319 & 29,401 & 2,276 & 120,970 & 253,994 & 3,389 & 2,121 & 644 & 411,336 & 68,556 & 414,725 & 69,120 \\
\hline System 2 & 3,875 & 29,401 & 819 & 33,164 & 276,142 & 2,827 & 1,606 & 523 & 342,702 & 57,117 & 345,528 & 57,588 \\
\hline System 3 & 3,525 & 29,401 & 2,007 & 36,520 & 242,364 & 2,023 & 1,383 & 507 & 313,684 & 52,281 & 315,707 & 52,618 \\
\hline
\end{tabular}

Notes: System 1 represents the simplest pasture system including Bermuda grass and ryegrass. System 2 includes a clover mix in addition to grasses in system 1 , and system 3 includes sorghum-Sudan hybrid and soybean in addition to the forage in system $2 . \mathrm{CH}_{4} \mathrm{~F}$, kilograms of $\mathrm{CO}_{2}$ equivalent of emissions from atmospheric $\mathrm{CH}_{4}$ flux; $\mathrm{CO}_{2} \mathrm{~F}$, kilograms of $\mathrm{CO}_{2}$ equivalent of emissions from atmospheric $\mathrm{CO}_{2}$ flux; DU, kilograms of $\mathrm{CO}_{2}$ equivalent emissions from diesel used; $\mathrm{EF}$, kilograms of $\mathrm{CO}_{2}$ equivalent of emissions from enteric fermentation; $\mathrm{HS}$, kilograms of $\mathrm{CO}_{2}$ equivalent of emissions from the hay surplus; $\mathrm{N}_{2} \mathrm{O} F$, kilograms of $\mathrm{CO}_{2}$ equivalent of emissions from atmospheric $\mathrm{N}_{2} \mathrm{O}$ flux; $\mathrm{NP}$, kilograms of $\mathrm{CO}_{2}$ equivalent of emissions from the nitrogen fertilizer production; PP, kilograms of $\mathrm{CO}_{2}$ equivalent of emissions due to pesticide production. 
Table 6. Annual Average Use of Pesticides by System, per Replication ( 6 Hectares or 6 Animals)

\begin{tabular}{lccccccc}
\hline \hline & \multicolumn{9}{c}{ Liters } & Kilograms \\
\cline { 2 - 7 } & $\begin{array}{c}\text { Roundup } \\
\text { Original }\end{array}$ & $\begin{array}{c}\text { Grazon } \\
\text { P }+\mathrm{D}\end{array}$ & Outrider & Gramoxone & Platoon & Malathion & $\begin{array}{c}\text { Sevin } \\
80 \mathrm{WP}\end{array}$ \\
\hline System 1 & 22.73 & 3.12 & 0.00 & 0.00 & 0.00 & 10.76 & 1.46 \\
System 2 & 18.18 & 4.61 & 0.03 & 0.63 & 0.58 & 6.94 & 1.02 \\
System 3 & 19.56 & 3.77 & 0.03 & 0.84 & 0.26 & 3.47 & 0.21 \\
\hline \hline
\end{tabular}

Notes: System 1 represents the simplest pasture system including Bermuda grass and ryegrass. System 2 includes a clover mix in addition to grasses in system 1, and system 3 includes sorghum-Sudan hybrid and soybean in addition to the forage in system 2 .

fertilizer were used annually for systems 1, 2, and 3, respectively. Due to the higher use of nitrogen fertilizer in system $1, \mathrm{CO}_{2}$ produced through $\mathrm{NP}, \mathrm{CH}_{4}$ flux, and $\mathrm{N}_{2} \mathrm{O}$ flux was highest in that system, which contributed to the highest GWP relative to the other pasture systems. Diesel consumption was highest in system 1 and lowest in system 3 due to higher machinery use for hay harvesting and nitrogen fertilizer application. On average, 724 liters, 548 liters, and 472 total liters of diesel were used annually for systems 1, 2, and 3, respectively. Therefore, $\mathrm{CO}_{2}$ equivalent emission due to the use of diesel was highest in system 1 and lowest in system 3 .

Four herbicides and two insecticides were used in the experiment. Annual average use of these pesticides per system is presented in the Table 6. The most heavily used pesticide was Roundup Original. On average, 23 liters, 18 liters, and 20 liters of Roundup Original were used in systems 1, 2, and 3, respectively. Outrider, Gramoxone, and Platoon were not used in system 1. Higher quantities of pesticides were used in system 1 than in systems 2 or $3 . \mathrm{CO}_{2}$ equivalent emission from PP was greater in system 1 than in systems 2 and 3, due to greater pesticide use in system 1 . Liebig et al. (2010) studied the impact of different grazing management strategies on GWP with three different grazing systems and found that heavily grazed and moderately grazed pastures had negative net GWP. Only the crested wheatgrass pasture had positive net GWP that differed significantly from two other systems. We cannot compare our results directly with theirs because they examined differences in soil organic carbon over a 50-year period.

Comparing profitability and GHG emissions, the following trade-offs are shown and presented in Table 7. System 3 had \$235 including labor expense (\$281 excluding labor expense) lower net profit per steer and $16,275 \mathrm{~kg}$ lower $\mathrm{CO}_{2}$ equivalent GWP per steer than system 1. Thus, if reduced $\mathrm{CO}_{2}$ equivalent emissions were valued at $\$ 0.014 / \mathrm{kg}$ including labor expense (or $\$ 0.017 / \mathrm{kg}$ excluding labor expense), then systems 1 and 3 would be economically 
Table 7. Trade-Offs between the Three Systems, per Animal

\begin{tabular}{lccc}
\hline \hline Comparison among Systems & $\begin{array}{c}\text { System } 3 \text { versus } \\
\text { System } 1\end{array}$ & $\begin{array}{c}\text { System } 3 \text { versus } \\
\text { System } 2\end{array}$ & $\begin{array}{c}\text { System } 2 \text { versus } \\
\text { System } 1\end{array}$ \\
\hline $\begin{array}{c}\text { Difference in profit (without } \\
\text { labor expense) }\end{array}$ & $-\$ 281^{\mathrm{a}}$ & $-\$ 212^{\mathrm{a}}$ & $-\$ 69$ \\
$\begin{array}{c}\text { Difference in profit } \\
\text { (including labor expense) }\end{array}$ & $-\$ 235^{\mathrm{a}}$ & $-\$ 194^{\mathrm{a}}$ & $-\$ 41$ \\
$\begin{array}{c}\text { Difference in GWP CO } 2 \\
\text { equivalent }\end{array}$ & $-16,275 \mathrm{~kg}$ & $-4,836 \mathrm{~kg}$ & $-11,439 \mathrm{~kg}$ \\
$\begin{array}{c}\text { Value of } \mathrm{CO}_{2} \text { to trade-off } \\
\text { (without labor expense) }\end{array}$ & $\$ 0.017 / \mathrm{kg}$ & $\$ 0.044 / \mathrm{kg}$ & $\$ 0.006 / \mathrm{kg}$ \\
$\begin{array}{l}\text { Value of } \mathrm{CO}_{2} \text { to trade-off } \\
\text { (including labor expense) }\end{array}$ & $\$ 0.014 / \mathrm{kg}$ & $\$ 0.040 / \mathrm{kg}$ & $\$ 0.004 / \mathrm{kg}$ \\
\hline \hline
\end{tabular}

a Statistically significant at $P<0.05$.

Notes: System 1 represents the simplest pasture system including Bermuda grass and ryegrass. System 2 includes a clover mix in addition to grasses in system 1, and system 3 includes sorghum-Sudan hybrid and soybean in addition to the forage in system 2. Currency amounts are in US\$.

equivalent. Similarly, system 3 had $\$ 194$ including labor expense $(\$ 212$ excluding labor expense) lower net profit per steer and 4,836 kg lower $\mathrm{CO}_{2}$ equivalent GWP per steer than system 2. Therefore, if reduced $\mathrm{CO}_{2}$ equivalent emissions were valued at $\$ 0.040 / \mathrm{kg}$ including labor expense $(\$ 0.044 / \mathrm{kg}$ excluding labor expense), then systems 2 and 3 would be economically equivalent. System 2 had $\$ 41$ including labor expense $(\$ 69$ excluding labor expense) lower economic profit per steer than system 1, which was not statistically different, and $11,439 \mathrm{~kg}$ lower $\mathrm{CO}_{2}$ equivalent GWP per steer than system 1 . Thus, system 2 appears to dominate system 1 because it produced statistically equivalent economic profit but had lower GWP than system 1.

\section{Conclusions}

From a cost and returns point of view, placing no economic value on carbon emissions, the least complex GFB production systems in this study, systems 1 and 2 , are more profitable than system 3 . Under this scenario, there is no conclusive evidence that Bermuda grass and ryegrass combinations differ in profitability from the Bermuda grass, ryegrass, rye, Dallis grass, and clover mix (berseem, red, and white clovers) system. These two systems were found to be more profitable than the more complex system 3 with Bermuda grass/ryegrass, rye, Dallis grass and clover mix, soybean, and sorghum-Sudan hybrid. From a risk preference perspective, the more risk averse producers would choose system 2 , whereas the less risk averse producers would choose system 1.

From an ecological view point considering GWP, the most complex system, system 3 , is the most favorable because it produced less $\mathrm{CO}_{2}$ equivalent GWP than the other two systems. System 1 produced the greatest $\mathrm{CO}_{2}$ equivalent GWP. This is based on the arithmetic average of $\mathrm{CO}_{2}$ equivalent 
emissions. Based on these results, the following trade-offs can be ascertained. If reduced $\mathrm{CO}_{2}$ equivalent emissions were valued at $\$ 0.014 / \mathrm{kg}$ including labor expense (or $\$ 0.017 / \mathrm{kg}$ excluding labor expense), then systems 1 and 3 would be economically equivalent. Similarly, if reduced $\mathrm{CO}_{2}$ equivalent emissions were valued at $\$ 0.040 / \mathrm{kg}$ including labor expense $(\$ 0.044 / \mathrm{kg}$ excluding labor expense), then systems 2 and 3 would be economically equivalent. System 2 may dominate system 1 because it produced statistically equivalent net profit and had numerically lower GWP than system 1 . Similar valuations of carbon credits were conducted by Williams et al. (2004) to compare no-tillage with conventional tillage operations for 10 years. They estimated carbon credit values in the range of $\$ 0.0086 / \mathrm{kg}$ to $\$ 0.065 / \mathrm{kg}$ to make no-till and conventional tillage operations economically equivalent. Together, these results suggest that carbon credit values of $>\$ 0.014 / \mathrm{kg}$ would have the potential to entice significant change in the use of agricultural production practices.

When choosing a forage system, both profitability and GHG impacts can be considered. The findings of this study would be helpful in selecting appropriate pasture systems to fulfill the increasing demand for GFB. To understand the net carbon emissions of pasture management more thoroughly, further studies are suggested over longer time periods. Economic, social, and ecological sustainability aspects should be taken into consideration when implementing extension programs for GFB production. To draw final conclusions about the selection of appropriate pasture systems, farmers must consider the complexity of management at the farm level with additional fencing and labor requirements. Because this is an experimental study within a research station, additional study at the farm level would be appropriate to evaluate its widespread applicability. Further, a working paper by Torrico et al. (2014) found for some groups (but not others) higher sensory scores for meat produced in our most complex system, system 3 . Here the higher sensory scores mean they liked system 3 beef better. This raises the question, if over time system 3 is shown to produce consistently higher sensory scores, will consumers be willing to pay premium prices for that beef such that the price for carbon would not have to be as high for producers to select system 3 ? This raises a rather complex question if the meats do not differ visually and do not grade differently and should be dealt with in further research.

\section{References}

Aberle, E.D., E.S. Reeves, M.D. Judge, R.E. Hunsley, and T.W. Perry. "Palatability and Muscle Characteristics of Cattle with Controlled Weight Gain: Time on a High Energy Diet.” Journal of Animal Science 52(1981):757-63.

Anderson, D.M. "Seasonal Stocking of Tobosa Managed under Continuous and Rotational Grazing." Journal of Range Management 41,1(1988):78-83.

Anderson, J.R., and J.L. Dillon. Risk Analysis in Dryland Farming Systems. Farming Systems Management Series No. 2. Rome, Italy: Food and Agricultural Organization of the United Nations, 1992. 
Antle, J.M., S.M. Capalbo, S. Mooney, E.T. Elliot, and K.H. Paustian. "Economic Analysis of Soil Carbon Sequestration: An integrated Assessment Approach." Journal of Agricultural and Resource Economics 26,2(2001):344-67.

Antle, J.M., and B.A. McCarl. "The Economics of Carbon Sequestration in Agricultural Soils." The International Yearbook of Environmental and Resource Economics 2002/2003. T. Tietenberg and H. Folmer, eds. Cheltenham, UK: Edward Elgar, 2002.

Bertelsen, B.S., D.B. Faulkner, D.D. Buskirk, and J.W. Castree. "Beef Cattle Performance and Forage Characteristics of Continuous, 6-Paddock, and 11-Paddock Grazing Systems.” Journal of Animal Science 71,6(1993):1381-89.

Boucher, R.W., and J.M. Gillespie. Projected Costs and Returns for Beef Cattle, Dairy and Forage Crop Production in Louisiana 2009. Agricultural Economics and Agribusiness Information Series No. 263. Baton Rouge, LA: Louisiana State University Agricultural Center, 2009.

- Projected Costs and Returns for Beef Cattle and Associated Forage Crop Production in Louisiana, 2010. Agricultural Economics and Agribusiness Information Series No. 268. Baton Rouge, LA: Louisiana State University Agricultural Center, 2010.

- Projected Costs and Returns for Beef Cattle and Associated Forage Crop Production in Louisiana, 2011. Agricultural Economics and Agribusiness Information Series No. 274. Baton Rouge, LA: Louisiana State University Agricultural Center, 2011.

Comerford, J.W., H.W. Harpster, E.H. Cash, V.H. Baumer, R.C. Stout, and R.L. Swope. "Animal and Forage Production and Economics of Three Grazing Systems of Beef Cattle.” Professional Animal Scientist 21(2005):455-64.

Cox, R.B., C.R. Kerth, J.G. Gentry, J.W. Prevatt, K.W. Braden, and W.R. Jones. "Determining Acceptance of Domestic Forage- or Grain-Finished Beef by Consumers from Three Southeastern U.S. States.” Journal of Food Science 71,7(2006):S542-46.

Fishell, V.K., E.D. Aberle, M.D. Judge, and T.W. Perry. "Palatability and Muscle Properties of Beef as Influenced by Preslaughter Growth Rate." Journal of Animal Science 61(1985):151-57.

Follett, R.F., and D.A. Reed. "Soil Carbon Sequestration in Grazing Lands: Societal Benefits and Policy Applications.” Rangeland Ecology \& Management 63,1(2010):4-15.

Gerrish, J. "Is Pasture-Finishing for You?" Beef. October 2, 2006. Internet site: http://beefmagazine.com/americancowman/pasture-and-range/pasture_finished_beef/ (Accessed June 6, 2011).

Gillespie, J.M., W. Wyatt, B. Venuto, D. Blouin, and R. Boucher. "The Roles of Labor and Profitability in Choosing a Grazing Strategy for Beef Production in the U.S. Gulf Coast Region." Journal of Agricultural and Applied Economics 40,1(2008):301-13.

Gwin, L. "Scaling-Up Sustainable Livestock Production: Innovation and Challenges for GrassFed Beef in the U.S.” Journal of Sustainable Agriculture 33,2(2009):189-209.

Hardaker, J.B., J.W. Richardson, G. Lien, and K.D. Schuman. "Stochastic Efficiency Analysis with Risk Aversion Bounds: A Simplified Approach.” Australian Journal of Agricultural and Resource Economics 48,2(2004):253-70.

Johnson, R.J. “U.S. Red Meat and Poultry Forecasts.” Livestock, Dairy, and Poultry Outlook. Washington, DC: U.S. Department of Agriculture, Economic Research Service, LDPM-215, May 16, 2012.

Kenward, M.G., and J.H. Roger. "Small Sample Inference for Fixed Effects from Restricted Maximum Likelihood.” Biometrics 53(1997):983-97.

Lal, R. “Carbon Emission from Farm Operations.” Environment International 30(2004):98190. 
Lewis, J.M., T.J. Klopfenstein, G.A. Pfeiffer, and R.A. Stock. “An Economic Evaluation of the Differences between Intensive and Extensive Beef Production Systems.” Journal of Animal Science 68(1990):2506-16.

Liebig, M.A., J.R. Gross, S.L. Kronberg, R.L. Phillips, and J.D. Hanson. "Grazing Management Contributions to Net Global Warming Potential: A Long-Term Evaluation in the Northern Great Plains.” Journal of Environmental Quality 39(2010):799-809.

Louisiana State University Agricultural Center and U.S. Department of Agriculture, National Agricultural Statistics Service, Louisiana Field Office. 2011 Louisiana Agricultural Statistics. A.E.A. Information Series No. 287, Department of Agricultural Economics and Agribusiness, LSU Agricultural Center, Baton Rouge, October, 2012.

Lozier, J., E. Rayburn, and J. Shaw. "Growing and Selling Pasture-Finished Beef: Results of a Nationwide Survey.” Journal of Sustainable Agriculture 25,2(2005):93-112.

Lyman, N., and L.L. Nalley. "Incentivizing Net Greenhouse Gas Emissions Reductions in Rice Production: The Case of Arkansas Rice." Journal of Agricultural and Applied Economics 45,1(2013):171-85.

McCluskey, J.J., T.I. Wahl, Q. Li, and P.R. Wandschneider. "U.S. Grass-Fed Beef: Marketing Health Benefits." Journal of Food Distribution Research 36,3(2005):1-8.

McFadden, B., L. Nalley, and M. Popp. "How Consumer Demand, Industry Pressure, and Government Policy Regarding Greenhouse Gas Emissions Could Affect Producer Selection of Grain Cultivars.” Paper presented at the 2011 Southern Agricultural Economics Association Annual Meeting, Corpus Christi, TX, February 5-8, 2011.

Mills, B. "Carving a Grass-Finished Niche." Beef 39,7(2003):16.

Nalley, L., M. Popp, and C. Fortin. "The Impact of Reducing Greenhouse Gas Emissions in Crop Agriculture: A Spatial- and Production-Level Analysis." Agricultural and Resource Economics Review 40,1(2011):63-80.

Nalley, L., M. Popp, and Z. Nierderman. "Embedded Seed Technology and Greenhouse Gas Emissions Reductions: A Meta-Analysis." Journal of Agricultural and Applied Economics 45,3(2013):523-35.

Oltjen, R.R., T.S. Rumsey, and P.A. Putnam. "All-Forage Diets for Finishing Beef Cattle." Journal of Animal Science 32(1971):327-33.

Pelletier, N., R. Pirog, and R. Rasmussen. "Comparative Life Cycle Environmental Impacts of Three Beef Production Strategies in the Upper Midwestern United States.” Agricultural Systems 103(2010):380-89.

Prevatt, J.W., C.R. Kerth, and D. Fields. Marketing Alabama-Grown, Forage-Fed Beef. Auburn, AL: Alabama Agricultural Experiment Station, Auburn University, Special Report No. 4, 2006. Internet site: http://www.aaes.auburn.edu/comm/ pubs/specialreports/sr_no4_marketing.pdf (Accessed June 6, 2011).

Richardson, J.W., K.D. Schumann, and P.A. Feldman. Simetar $($ : : Simulation \& Econometrics to Analyze Risk. College Station, TX: Simetar, 2008.

Schupp, A., T. Binder, W. McKnight, D. Smith, J. Carpenter, and F. Wiegmann. Acceptance of Beef Finished on Forages or with Limited Grain. Baton Rouge, LA: Agricultural Experiment Station, Louisiana State University, Bulletin No. 714, 1979.

Steinberg, E.L., and J.W. Comerford. "Case Study: A Survey of Pasture-Finished Beef Producers in the Northeastern United States." Professional Animal Scientist 25(2009):104-8.

Torrico, D.D., W. Jirangrat, G. Scaglia, F. Malekian, M.E. Janes, K.W. McMillin, and W. Prinyawiwatkul. "Proximate and Fatty Acid Compositions and Sensory Acceptability of Hispanic Consumers towards Rib-Eye Steaks from Forage-Finished 
Steer.” Working paper, Louisiana State University Agricultural Center, Baton Rouge, LA, 2014.

Umberger, W.J., D.M. Feuz, C.R. Calkins, and K. Killinger-Mann. "U.S. Consumer Preference and Willingness-to-Pay for Domestic Corn-Fed Beef versus International Grass-Fed Beef Measured through an Experimental Auction.” Agribusiness 18,4(2002):491-504.

U.S. Department of Agriculture, Agricultural Marketing Service, Grass Fed Marketing Claim Standards 2007. "United States Standards for Livestock and Meat Marketing Claims, Grass (Forage) Fed Claim for Ruminant Livestock and the Meat Products Derived from Such Livestock." Notice. Federal Register 72,199(October 16, 2007):5863158637. Internet site: http://www.ams.usda.gov/AMSv1.0/ams.fetchTemplateData. do? template $=$ TemplateN\&rightNav1 $=$ GrassFedMarketingClaimStandards\&topNav= \&leftNav $=$ GradingCertificationandVerfication \&page $=$ GrassFedMarketingClaims $\&$ resultType (Accessed on October 14, 2014).

U.S. Department of Agriculture-Texas Department of Agricultural Marketing News. Weekly Texas Hay Report. Washington, DC: U.S. Department of Agriculture, Agricultural Marketing Service, April 9, 2010.

- Weekly Texas Hay Report. Washington, DC: U.S. Department of Agriculture, Agricultural Marketing Service, April 8, 2011.

- Weekly Texas Hay Report. Washington, DC: U.S. Department of Agriculture, Agricultural Marketing Service, April 6, 2012.

West, T.O., and G. Marland. "A Synthesis of Carbon Sequestration, Carbon Emissions, and Net Carbon Flux in Agriculture: Comparing Tillage Practices in the United States.” Agriculture, Ecosystems \& Environment 91(2002):217-32.

Williams, J.R., R.G. Nelson, M.M. Claassen, and C.W. Rice. "Carbon Sequestration in Soil with Consideration of $\mathrm{CO}_{2}$ Emissions from Production Inputs: An Economic Analysis." Environmental Management 33,1S(2004):S264-73.

Wright, I.A. "Future Prospects for Meat and Milk from Grass-Based Systems." Grasslands: Developments, Opportunities, Perspectives. S.G. Reynolds and J. Frame, eds. Enfield, NH: Science Publishers, 2005.

Young, A.W., and R.G. Kauffman. "Evaluation of Beef from Steers Fed Grain, Corn Silage or Haylage-Corn Silage Diets.” Journal of Animal Science 46(1978):41-47.

Zeuli, K.A., and J.R. Skees. "Will Southern Agriculture Play a Role in a Carbon Market?" Journal of Agricultural and Applied Economics 32,2(2000):235-48.

\section{Appendix}

Table A1. Specific Gravity and Active Ingredient of Pesticides

\begin{tabular}{lccc}
\hline \hline Pesticides & Specific Gravity & Active Ingredient & Percentage Active Ingredient \\
\hline Roundup Original & 1.36 & Glyphosate & 49 \\
Grazon P+D & 1.143 & $2,4-\mathrm{D}+$ picloram & $39.6+10.2$ \\
Gramoxone & 1.13 & Paraquat & 43.8 \\
Outrider & 1.55 & Sulfosulfuran & 75 \\
Platoon & 1.161 & Dimethylamine salt of 2,4-D & 47.3 \\
Malathion 57EC & 1.0768 & Malathion & 57 \\
Sevin 80WP & - & Carbaryl & 80 \\
\hline \hline
\end{tabular}

Note: Specific gravity and percentage of active ingredient contained in pesticides are as per the material safety data sheets of the respective pesticides. 